\title{
Correlation of growth-related traits and their effects on body weight of the mud crab (Scylla paramamosain)
}

\author{
H.Y. Ma, C.Y. Ma, L.B. Ma, Z. Xu, N.N. Feng and Z.G. Qiao \\ Key Laboratory of East China Sea and Oceanic Fishery Resources Exploitation, \\ Ministry of Agriculture, East China Sea Fisheries Research Institute, \\ Chinese Academy of Fishery Sciences, Shanghai, China \\ Corresponding author: L.B. Ma \\ E-mail: malingbo@vip.sina.com
}

Genet. Mol. Res. 12 (4): 4127-4136 (2013)

Received March 4, 2013

Accepted August 15, 2013

Published October 1, 2013

DOI http://dx.doi.org/10.4238/2013.October.1.3

\begin{abstract}
In this study, we analyzed the correlation of 20 growthrelated traits and their effects on body weight of Scylla paramamosain. The correlation coefficients in all trait pairs were significantly high, ranging from 0.551 to 0.999 . Among $19 X-Y$ pairs, the correlation coefficient between traits $X_{1}$ and $Y$ was the highest, whereas that between $X_{13}$ and $Y$ was the lowest. Path analysis indicated that only two traits $\left(X_{1}\right.$ and $\left.X_{14}\right)$ can significantly affect body weight ( $Y$ ) directly, with the path coefficients being 0.800 and 0.198 , respectively. The determination coefficients $\left(d_{\mathrm{i}}\right)$ of traits $X_{1}$ and $X_{14}$ to body weight were 0.640 and 0.039 , respectively, and the total $d_{\mathrm{i}}$ was 0.965 , indicating that both traits were the key factors affecting body weight. Moreover, traits $X_{1}$ and $X_{14}$ were confirmed to be significantly related to body weight. Finally, a best-fit linear regression equation was constructed as $Y=$ $4.192 X_{1}+2.242 X_{14}-169.737$.
\end{abstract}

Key words: Scylla paramamosain; Growth-related traits; Path analysis; Correlation analysis; Multiple regression equation 


\section{INTRODUCTION}

Selective breeding schemes, which can improve economically important traits of cultured aquatic species (Neira et al., 2006; Nielsen et al., 2009; Bangera et al., 2011), have become more and more popular in aquaculture. Studies on phenotypic and genetic relationships among growth-related traits have been reported in many aquaculture species, including pearl oyster (Pinctada martensii; Deng et al., 2008), common carp (Cyprinus carpio; Wang, 2009), small abalone (Haliotis diversicolor; You et al., 2010), Japanese flounder (Paralichthys olivaceus; Tian et al., 2011), and sea urchin (Strongylocentrotus intermedius; Chang et al., 2012). So far, more statistical methods have been employed to estimate the relationships among economically important traits, such as correlation analysis, path analysis, and regression analysis. For example, using correlation and path analyses, Deng et al. (2008) reported that shell length, shell width, shell height, shell weight, and total weight were significantly correlated $(\mathrm{P}<0.05)$, whereas shell weight had the largest positive and direct effects on total weight $\left(P_{\mathrm{i}}=0.6356\right)$. Alicli et al. (2012) described the relationship between lower jaw fork length and round weight through a regression equation $\left(W=1 \times 10^{-6} L^{3.46}\right)$.

The mud crab (Scylla paramamosain) is a large carnivorous portunid crab, naturally distributed along the southeastern coastal region of China. This crab is considered to be an important marine species for fisheries resources and aquaculture in China, owing to its abundant fishing yields, fast growth rate, and high commercial values. China has a long history (more than 100 years) of farming S. paramamosain (Cowan, 1985; Shen and Lai, 1994). For the year 2011, the total culture area of S. paramamosain had expanded to more than $270 \times 10^{6} \mathrm{~m}^{2}$, and the output reached more than 110,000 tons in China. In the past decade, scientific studies on $S$. paramamosain have mainly focused on its reproductive biology (Djunaidah et al., 2003; Zeng, 2007), culture biology (Nghia et al., 2007; Ut et al., 2007), functional genes (Rosa et al., 2008; Wang et al., 2012), population genetic diversity (Ma et al., 2011a, 2012; Shu et al., 2011), and molecular markers (Xu et al., 2009; Ma et al., 2011b,c). However, little information about traditional selective breeding or molecular marker-based selection is available for $S$. paramamosain, although the genetic differences among different $\mathrm{F}_{1}$ families have been investigated by microsatellite markers (Cui et al., 2011).

In the present study, we analyzed the relationships of growth-related traits of the mud crab (S. paramamosain) using correlation analysis, estimated the contribution of growth-related traits to body weight using path analysis, and constructed a best-fit linear multiple regression equation using regression analysis. This study will provide useful information for better understanding the relationships among growth-related traits and for selective breeding of this important crab and other crustacean crab species.

\section{MATERIAL AND METHODS}

\section{Crab sampling}

A total of 149 specimens of $S$. paramamosain were captured randomly from four different locations in the southeastern coastal regions of China between December 2010 and October 2011: Wenzhou $(\mathrm{N}=45)$, Shenzhen $(\mathrm{N}=38)$, Zhanjiang $(\mathrm{N}=39)$, and Wenchang ( =27) (Figure 1 and Table 1). 


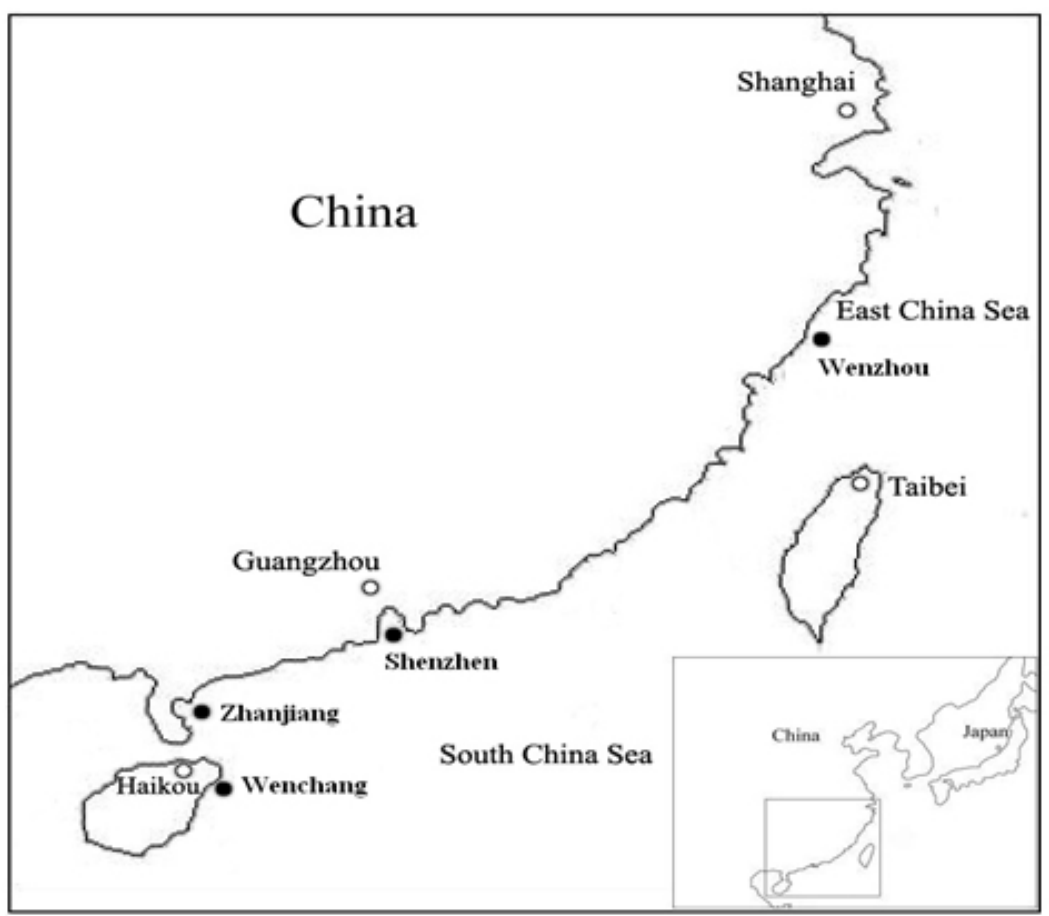

Figure 1. Geographic locations of Scylla parmamosain sampled in this study. $\bullet$ = sampling location.

\begin{tabular}{|c|c|c|c|c|}
\hline Location & date & Female & Male & Total \\
\hline Wenzhou & September 2011 & 16 & 29 & 45 \\
\hline Shenzhen & December 2010 & 27 & 11 & 38 \\
\hline Zhanjiang & December 2010 & 20 & 19 & 39 \\
\hline Wenchang & October 2011 & 14 & 13 & 27 \\
\hline Total & & 77 & 72 & 149 \\
\hline
\end{tabular}

\section{Growth-related traits measure}

In total, 20 growth-related traits were measured according to the methods of Keenan et al. (1998) and Gao et al. (2008), including carapace length $\left(X_{1}\right)$, carapace width $\left(X_{2}\right)$, internal carapace width $\left(X_{3}\right)$, carapace frontal width $\left(X_{4}\right)$, abdomen width $\left(X_{5}\right)$, body height $\left(X_{6}\right)$, carapace width at spine $8\left(X_{7}\right)$, distance between frontal median spines $\left(X_{8}\right)$, distance between frontal lateral spines $\left(X_{9}\right)$, distance between lateral spine $1\left(X_{10}\right)$, distance between lateral spine $2\left(X_{11}\right)$, fixed finger length of the claw $\left(X_{12}\right)$, fixed finger width of the claw $\left(X_{13}\right)$, fixed finger height of the claw $\left(X_{14}\right)$, meropodit length of peraeopod $1\left(X_{15}\right)$, meropodit length of peraeopod $2\left(X_{16}\right)$, meropodit length of peraeopod $3\left(X_{17}\right)$, the 4th pereopod dactyl length $\left(X_{18}\right)$, the 4 th pereopod dactyl width $\left(X_{19}\right)$, and body weight $(Y)$. The former 19 morphological traits were measured to the nearest $0.02 \mathrm{~mm}$ with Vernier callipers. The body weight of the crab was measured to an accuracy of $0.01 \mathrm{~g}$ with a digital electronic balance. 


\section{Sex identification}

The sex of specimens was identified based on the shape of the abdomen. The female crab has a wider and more globular abdomen, whereas the male crab has a narrow and straight abdomen (Ikhwanuddin et al., 2011).

\section{Data analysis}

The mean value and standard deviation of each trait were calculated using the software SPSS version 11.5. The coefficient of variation $(C V)$ of each trait was estimated using the following formula: $C V=$ (standard deviation / mean) $\mathrm{x} 100 \%$. The path analysis was carried out using the software SPSS 11.5, as described by Du and Chen (2010). The correlation analysis and multiple regression analysis were also performed using SPSS 11.5. The multiple regression equation was constructed as follows: if the correlation variables $Y, X_{1}, X_{2}$, and $X_{3}$ exist in a linear equation, the regression equation is described as $Y$ $=b_{0}+b_{1} X_{1}+b_{2} X_{2}+b_{3} X_{3}$, where $Y$ is the dependent variable, $X_{1}, X_{2}$, and $X_{3}$ are the independent variables, $b_{0}$ is the constant, and $b_{1}, b_{2}$, and $b_{3}$ are the partial regression coefficients for $Y$ on $X_{1}, X_{2}$, and $X_{3}$.

The determination coefficient was calculated using the alternative formulas: (1) $d_{\mathrm{i}}=$ $P_{i}^{2}$; and (2) $d_{\mathrm{ij}}=2 r_{\mathrm{ij}} \times P_{\mathrm{i}} \times P_{\mathrm{j}}$, where $d_{\mathrm{i}}$ is the effect of a single trait $\mathrm{i}$ on body weight, $d_{\mathrm{ij}}$ is the effect of traits $\mathrm{i}$ and $\mathrm{j}$ on body weight, $P_{\mathrm{i}}$ is the path coefficient of the single trait $\mathrm{i}$ to body weight, $r_{\mathrm{ij}}$ is the correlation coefficient between traits $\mathrm{i}$ and $\mathrm{j}$, and $P_{\mathrm{j}}$ is the path coefficient of the single trait $\mathrm{j}$ to body weight.

\section{RESULTS}

\section{Sex ratio in samples}

Of 149 specimens examined, 77 were female and 72 were male (Table 1). The sex ratio (female:male) of this species was estimated at 1:0.94. No significant difference was found between the amounts of female and male compared with the ideal ratio 1:1 (P $>0.05)$.

\section{Descriptive statistics of growth-related traits}

The mean values, standard deviations, and coefficients of variation of the 20 growth-related traits are listed in Table 2 . The coefficient of variation of body weight $(Y)$ was the largest $(C V=56.09 \%)$, whereas that of distance between lateral spine $1\left(X_{10}\right)$ was the lowest $(C V=16.91 \%)$. The standard deviation of body weight $(Y)$ was the largest $(\mathrm{SD}=51.71)$, whereas that of distance between frontal lateral spines $\left(X_{9}\right)$ was the lowest $(\mathrm{SD}=0.70)$.

\section{Correlation coefficients among growth-related traits}

The relationships among the 20 growth-related traits were estimated by correlation 
analysis and the results are shown in Table 3. A significantly positive correlation was detected in all 190 trait pairs $(\mathrm{P}<0.01)$. The correlation coefficients $(\mathrm{r})$ ranged from $0.551\left(X_{9}\right.$ and $\left.X_{13}\right)$ to $0.999\left(X_{5}\right.$ and $\left.X_{7}\right)$. A significantly positive correlation $(\mathrm{P}<0.01)$ was observed between body weight $(Y)$ and each of the other 19 morphological traits, with the $\mathrm{r}$ value ranging from 0.614 (between $Y$ and $X_{13}$ ) to 0.979 (between $Y$ and $X_{1}$ ).

Table 2. Descriptive statistics of growth-related traits of Scylla paramamosain.

\begin{tabular}{lccccc}
\hline Trait & Minimum & Maximum & Mean & Standard deviation $(\mathrm{SD})$ & Coefficient of variation $(C V, \%)$ \\
\hline$X_{1}(\mathrm{~mm})$ & 36.18 & 80.44 & 52.06 & 9.87 & 18.96 \\
$X_{2}(\mathrm{~mm})$ & 55.92 & 120.78 & 79.15 & 15.16 & 19.15 \\
$X_{3}(\mathrm{~mm})$ & 51.64 & 114.50 & 74.18 & 14.19 & 19.13 \\
$X_{4}(\mathrm{~mm})$ & 22.22 & 44.10 & 30.27 & 4.84 & 15.99 \\
$X_{5}(\mathrm{~mm})$ & 18.52 & 53.22 & 28.17 & 7.25 & 25.74 \\
$X_{6}(\mathrm{~mm})$ & 21.28 & 47.06 & 31.04 & 5.87 & 18.91 \\
$X_{7}(\mathrm{~mm})$ & 53.82 & 118.20 & 77.19 & 14.74 & 19.10 \\
$X_{8}(\mathrm{~mm})$ & 2.60 & 6.68 & 4.13 & 0.78 & 18.89 \\
$X_{9}(\mathrm{~mm})$ & 2.80 & 5.94 & 4.14 & 0.70 & 16.91 \\
$X_{10}(\mathrm{~mm})$ & 28.74 & 57.26 & 39.42 & 6.31 & 16.01 \\
$X_{11}(\mathrm{~mm})$ & 34.26 & 70.50 & 47.71 & 8.11 & 17.00 \\
$X_{12}(\mathrm{~mm})$ & 33.24 & 75.92 & 48.56 & 9.32 & 19.19 \\
$X_{13}(\mathrm{~mm})$ & 8.30 & 55.60 & 13.18 & 4.46 & 33.84 \\
$X_{14}(\mathrm{~mm})$ & 12.48 & 35.50 & 19.48 & 4.57 & 23.46 \\
$X_{15}(\mathrm{~mm})$ & 17.50 & 38.58 & 25.68 & 4.49 & 17.48 \\
$X_{16}(\mathrm{~mm})$ & 19.22 & 41.10 & 27.64 & 4.97 & 17.98 \\
$X_{17}(\mathrm{~mm})$ & 16.64 & 39.22 & 23.41 & 4.17 & 17.81 \\
$X_{18}(\mathrm{~mm})$ & 14.00 & 40.80 & 23.41 & 5.28 & 22.55 \\
$X_{19}(\mathrm{~mm})$ & 7.22 & 19.46 & 11.73 & 2.57 & 21.91 \\
$Y(\mathrm{~g})$ & 28.33 & 276.60 & 92.19 & 51.71 & 56.09
\end{tabular}

$X_{1}=$ carapace length $X_{2}=$ carapace width $X_{3}=$ internal carapace width; $X_{4}=$ carapace frontal width; $X_{5}=$ abdomen width; $X_{6}=$ body height; $X_{7}=$ carapace width at spine $8 ; X_{8}=$ distance between frontal median spines; $X_{9}=$ distance between frontal lateral spines; $X_{10}=$ distance between lateral spine $1 ; X_{11}=$ distance between lateral spine $2 ; X_{12}$ = fixed finger length of the claw; $X_{13}=$ fixed finger width of the claw; $X_{14}=$ fixed finger height of the claw; $X_{15}=$ meropodit length of peraeopod $1 ; X_{16}=$ meropodit length of peraeopod $2 ; X_{17}=$ meropodit length of peraeopod 3; $X_{18}=$ the fourth periopod dactyl length; $X_{19}=$ the fourth periopod dactyl width; $Y=$ body weight.

\section{Path coefficients and determination coefficients}

Of 19 morphological growth-related traits, only two $\left(X_{1}\right.$ and $\left.X_{14}\right)$ showed significant effects on body weight directly $(\mathrm{P}<0.05)$ (Table 4$)$. Trait $X_{1}$ showed the largest direct effect $\left(P_{\mathrm{i}}=0.800\right)$ on body weight, whereas $X_{14}$ showed the lowest indirect effect $\left(P_{\mathrm{i}}=0.179\right)$ on body weight. Trait $X_{14}$ was the second leading factor affecting body weight, with the direct and indirect effects being 0.198 and 0.722 , respectively. The multiple correlation coefficient $\left(\mathrm{R}^{2}\right)$ was 0.966 (higher than 0.85 ), indicating that $X_{1}$ and $X_{14}$ were the key growth-related traits affecting body weight.

The determination coefficients of morphological traits to body weight are shown in Table 5. The determination coefficient of $X_{1}$ was the largest (0.640), the co-determination coefficient of $X_{1}$ and $X_{14}$ was relatively less (0.286), and the determination coefficient of $X_{14}$ was the lowest $(0.039)$. The total determination coefficient $(d=0.965)$ of morphological traits to body weight was approximately equal to the multiple correlation coefficient $\left(\mathrm{R}^{2}=0.966\right)$ of morphological traits to body weight. 


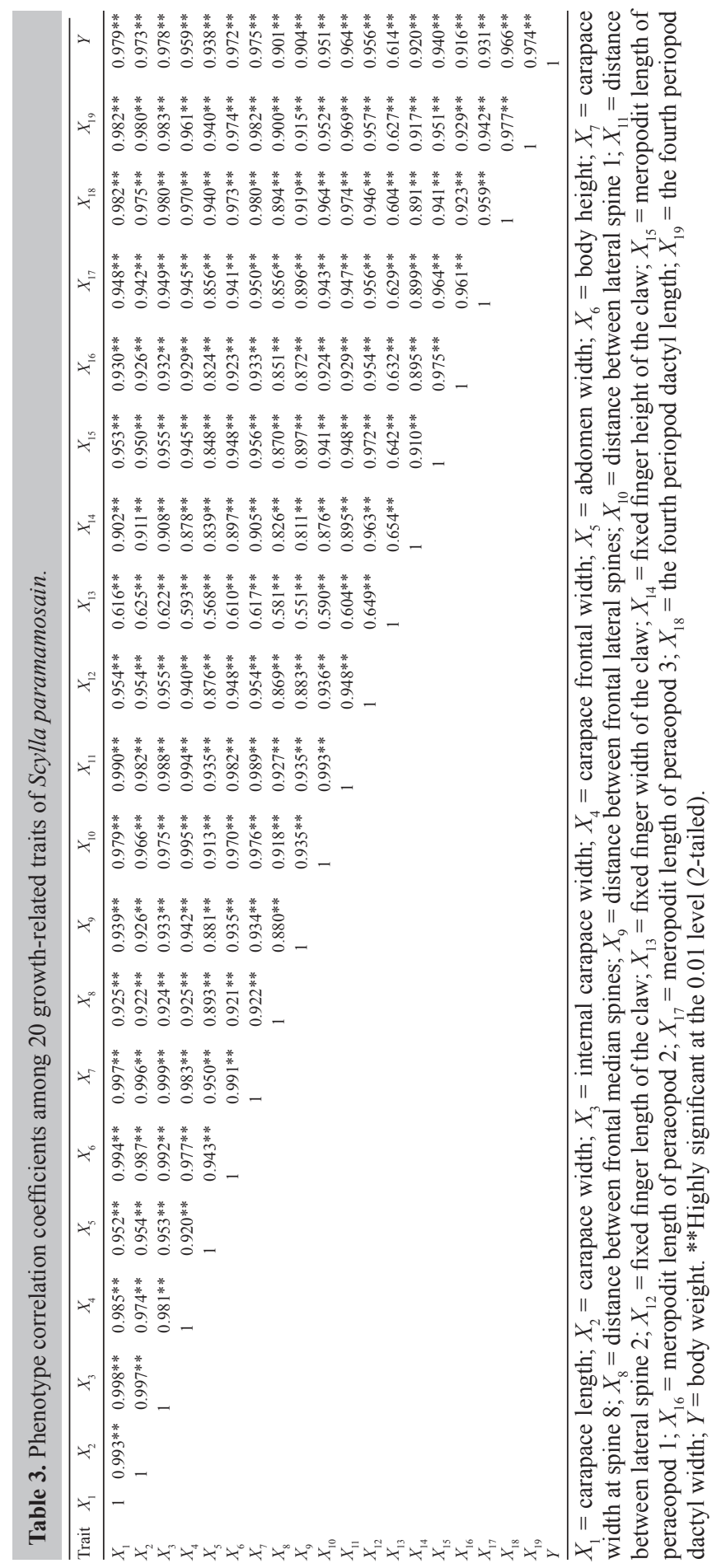


Table 4. Direct and indirect effects of morphologic traits on body weight of Scylla paramamosain.

\begin{tabular}{lcccc}
\hline Trait & Correlation coefficient $\left(r_{\mathrm{ij}}\right)$ & Direct effect $\left(P_{\mathrm{i}}\right)$ & Total of indirect effect $(\Sigma)$ & \multicolumn{2}{c}{ Indirect effect $\left(r_{\mathrm{ij}} \mathrm{x} P_{\mathrm{j}}\right)$} \\
\cline { 3 - 5 } & & & $X_{1}$ & $X_{14}$ \\
\hline$X_{1}$ & 0.979 & 0.800 & 0.179 & 0.179 \\
$X_{14}$ & 0.920 & 0.198 & 0.722 & 0.722 \\
\hline$X_{1}=$ carapace length $X_{14}=$ fixed finger height of the claw.
\end{tabular}

Table 5. Determination coefficients of morphologic traits to body weight of Scylla paramamosain.

\begin{tabular}{lcc}
\hline Trait & $X_{1}$ & $X_{14}$ \\
\hline$X_{1}$ & 0.640 & 0.286 \\
$X_{14}$ & 0.039 \\
\hline$X_{1}=$ carapace length; $X_{14}=$ fixed finger height of the claw.
\end{tabular}

\section{Construction of multiple regression equation}

The regression relationship between body weight and other morphological traits was estimated by the following steps: first by testing the significance of partial regression coefficients of different traits and then by stepwise removing nonsignificant morphological traits. The results indicated that body weight showed a significant regression relationship to only two traits $\left(X_{1}\right.$ and $\left.X_{14}\right)(\mathrm{P}<0.01$; Table 6). A best-fit linear multiple regression equation was constructed as follows: $Y=4.192 X_{1}+2.242 X_{14}-169.737$. The constant and partial coefficients of regression equation were tested by the $t$-test, which suggested a significant effect of them on body weight $(\mathrm{P}<0.01$; Table 7$)$.

Table 6. Analysis of variance (ANOVA) of multiple regression equation of Scylla paramamosain.

\begin{tabular}{lcccc}
\hline Index & Sum of squares & d.f. & Mean square & $F$ \\
\hline Regression analysis & 382111.28 & 2 & 191055.64 & 2045.19 \\
Residual & 13638.92 & 146 & 93.42 & 0.000 \\
Total & 395750.21 & 148 & Adjusted $R^{2}=0.965$ & SD $=9.665$ \\
Multiple correlation & $R=0.983$ & $R^{2}=0.966$ & P & \\
\hline
\end{tabular}

Table 7. The $t$-test for constant and partial regression coefficients in multiple regression equation of Scylla
paramamosain.
\begin{tabular}{lcccc}
\hline Index & Partial coefficient & Standard error & $t$-value & $\mathrm{P}$ \\
\hline Constant & -169.737 & 4.359 & -38.936 & 0.000 \\
$X_{1}$ & 4.192 & 0.186 & 22.508 & 0.000 \\
$X_{14}$ & 2.242 & 0.402 & 5.573 & 0.000 \\
\hline
\end{tabular}

$X_{1}=$ carapace length; $X_{14}=$ fixed finger height of the claw.

\section{DISCUSSION}

Estimation of the relationship among growth-related traits is an important issue for quantitative genetics and selective breeding. In the present study, we analyzed the correlation among 20 growth-related traits of $S$. paramamosain that showed abundant variation of these 
traits. Body weight $(Y)$ had the largest variation $(C V=56.09 \%)$, whereas the distance between lateral spine $1\left(X_{10}\right)$ showed the lowest variation $(C V=16.91 \%)$. These various phenotypic traits can provide considerable material for sustained improvement of the breeding process. Similar to the high variation of phenotypic traits, a high level of genetic diversity was observed by using microsatellites, single nucleotide polymorphisms, and mitochondrial DNA (Ma et al., 2011a,b, 2012). Morphological traits, such as body length and body weight, are often used as criteria for selecting excellent individuals in artificial breeding (Neira et al., 2006; Takeshita and Soyano, 2009). For Pinctada martensii, the shell length, shell width, shell height, and total weight were found to be significantly correlated to one another $(\mathrm{P}<0.05)$ (Deng et al., 2008). For Portunus trituberculatus, the five growth-related traits of carapace length, carapace width, internal carapace width, body height, and body weight were confirmed to be significantly correlated to one another $(\mathrm{P}<0.01)$ (Liu et al., 2009). In this study, all 20 growth-related traits were observed to be significantly positively correlated to one another $(\mathrm{P}<0.01)$. This means that it is feasible to select one targeting trait through selecting other one or more traits in the $S$. paramamosain breeding process. The high correlation among traits may be resulting from pleiotropy in the determination of these traits (Falconer, 1981).

Path analysis is an effective method for multiple statistics, which can separate the total effects of independent variables on dependent variables into direct and indirect effects (Rodrigueza et al., 2001). In this study, out of 19 morphological traits, two $\left(X_{1}\right.$ and $\left.X_{14}\right)$ showed significant direct effects on body weight $(\mathrm{P}<0.05)$. The multiple correlation coefficient between morphological traits and body weight was high (more than 0.85 ) and approximately equal to the determination coefficient; hence, the traits $X_{1}$ and $X_{14}$ could be considered as the key factors affecting the body weight of $S$. paramamosain. By using path analysis, the main factors affecting body weight have been observed in other aquaculture animals, such as Eriocheir sinensis (Geng et al., 2007), Pinctada martensii (Deng et al., 2008), and Portunus trituberculatus (Liu et al., 2009). In contrast, the multiple correlation coefficient for edible tissue weight of 2- and 3-year-old Ruditapes philippinarum was tested to be lower than 0.85 , indicating that some other factors affecting edible tissue weight may be omitted (Huo et al., 2010). A best-fit linear multiple regression equation was successfully constructed for $S$. paramamosain, which can be easily used to estimate the body weight $(Y)$ through the carapace length $\left(X_{1}\right)$ and fixed finger height of the claw $\left(X_{14}\right)$.

\section{CONCLUSIONS}

The high correlation among 20 growth-related traits was first tested in the important crab species, mud crab (S. paramamosain). In addition, two growth-related traits $\left(X_{1}\right.$ and $\left.X_{14}\right)$ showed significant direct effects on body weight. Finally, a multiple regression equation was constructed relating body weight and the above two growth-related traits. This study will be useful for further research about the relationships among growth-related traits and for selective breeding of this important crab and other crustacean species.

\section{ACKNOWLEDGMENTS}

We thank Dr. Wei Song for assistance in partial sample collection. Research supported by the National Non-Profit Institutes (East China Sea Fisheries Research Institute; 
\#2011M05), the National Natural Science Foundation of China (\#31001106), and the Science and Technology Commission of Shanghai Municipality (\#10JC1418600).

\section{REFERENCES}

Alicli TZ, Oray IK, Karakulak FS and Kahraman AE (2012). Age, sex ratio, length-weight relationships and reproductive biology of Mediterranean swordfish, Xiphias gladius L., 1758, in the eastern Mediterranean. Afr. J. Biotechnol. 11: 3673-3680.

Bangera R, Odegard J, Prabel AK, Mortensen A, et al. (2011). Genetic correlations between growth rate and resistance to vibriosis and viral nervous necrosis in Atlantic cod (Gadus morhua L). Aquaculture 317: 67-73.

Chang Y, Zhang W, Zhao C and Song J (2012). Estimates of heritabilities and genetic correlations for growth and gonad traits in the sea urchin, Strongylocentrotus intermedius. Aquac. Res. 43: 271-280.

Cowan L (1985). Crab farming in Japan, Taiwan and the Philippines. Queensland Department of Primary Industries, Queensland, Australia.

Cui HY, Ma HY, Ma CY and Qiao ZG (2011). Genetic diversity among different families of mud crab Scylla paramamosain by microsatellite markers. Mar. Fish. 33: 274-281.

Deng Y, Du XD, Wang Q, Fu S, et al. (2008). Correlation and path analysis for growth traits in F1 population of pearl oyster, Pinctada martensii. Mar. Sci. B 10: 68-73.

Djunaidah IS, Wille M, Kontara EK and Sorgeloos P (2003). Reproductive performance and offspring quality in mud crab (Scylla paramamosain) broodstock fed different diets. Aquac. Int. 11: 3-15.

Du JJ and Chen ZW (2010). Carrying out path analysis by linear regression of SPSS. B Biol. 45: 4-6.

Falconer DS (1981). Introduction to Quantitative Genetics. Longman Inc., New York.

Gao BQ, Liu P, Li J, Chi H, et al. (2008). The relationship between morphometric characters and body weight of Portunus trituberculatus. Mar. Fish Res. 29: 44-50.

Geng XY, Wang XH, Sun JS and Zhang YS (2007). Morphometric attributes to body weight for juvenile crab, Eriocheir sinensis. Oceanol. Limnol. Sin. 38: 49-54.

Huo ZM, Yan XW, Zhao LQ, Zhang YH, et al. (2010). Effects of shell morphological traits on the weight traits of Manila clam (Ruditapes philippinarum). Acta Ecol. Sin. 30: 251-256.

Ikhwanuddin M, Azmie G, Juariah HM, Zakaria MZ, et al. (2011). Biological information and population features of mud crab, genus Scylla from mangrove areas of Sarawak, Malaysia. Fish. Res. 108: 299-306.

Keenan CP, Davie PJF and Mann DL (1998). A revision of the genus Scylla de Haan, 1833 (Crustacea: Decapoda: Brachyura: Portunidae). Raffles B Zool. 46: 217-245.

Liu L, Li J, Gao BQ, Liu P, et al. (2009). Correlation of growth traits of Portunus trituberculatus at the different ages and its impact on body weight. J. Fish. China 33: 964-971.

Ma HY, Ma CY and Ma LB (2011a). Population genetic diversity of mud crab (Scylla paramamosain) in Hainan Island of China based on mitochondrial DNA. Biochem. Syst. Ecol. 39: 434-440.

Ma HY, Ma QQ, Ma CY and Ma LB (2011b). Isolation and characterization of gene-derived single nucleotide polymorphism (SNP) markers in Scylla paramamosain. Biochem. Syst. Ecol. 39: 419-424.

Ma HY, Ma CY, Ma LB, Zhang FY, et al. (2011c). Isolation and characterization of 54 polymorphic microsatellite markers in Scylla paramamosain by FIASCO approach. J. World Aquac. Soc. 42: 591-597.

Ma HY, Cui HY, Ma CY and Ma LB (2012). High genetic diversity and low differentiation in mud crab (Scylla paramamosain) along the southeastern coast of China revealed by microsatellite markers. J. Exp. Biol. 215: 3120-3125.

Neira R, Diaz NF, Gall GAE, Gallardo JA, et al. (2006). Genetic improvement in coho salmon (Oncorhynchus kisutch). II: Selection response for early spawning date. Aquaculture 257: 1-8.

Nghia TT, Wille M, Binh TC, Thanh HP, et al. (2007). Improved techniques for rearing mud crab Scylla paramamosain (Estampador 1949) larvae. Aquac. Res. 38: 1539-1553.

Nielsen HM, Sonesson AK, Yazdi H and Meuwissen THE (2009). Comparison of accuracy of genome-wide and BLUP breeding value estimates in sib based aquaculture breeding schemes. Aquaculture 289: 259-264.

Rodrigueza DJ, Angulo-Sanchezb JL and Rodriguez-Garciaa R (2001). Correlation and path coefficient analyses of the agronomic traits of a native population of guayule plants. Ind. Crops Prod. 14: 93-103.

Rosa RD, Stoco PH and Barracco MA (2008). Cloning and characterisation of cDNA sequences encoding for antilipopolysaccharide factors (ALFs) in Brazilian palaemonid and penaeid shrimps. Fish Shellfish Immunol. 25: 693-696.

Shen Y and Lai Q (1994). Present status of mangrove crab (Scylla serrata (Forskål)) culture in China. ICLARM Quart. 17: $28-29$. 
Shu MA, Zhou YF, Zhu XY, Zhao XF, et al. (2011). Microsatellite analysis on genetic diversity of seven wild populations of Scylla paramamosain in China. J. Fish. China 35: 977-984.

Takeshita A and Soyano K (2009). Effects of fish size and size-grading on cannibalistic mortality in hatchery-reared orange-spotted grouper Epinephelus coioides juveniles. Fish. Sci. 75: 1253-1258.

Tian Y, Xu T, Liang Y and Chen S (2011). Estimates of genetic and phenotypic parameters for weight and length in Paralichthys olivaceus (Temminck et Schlegel). Acta Oceanol. Sin. 30: 58-64.

Ut VN, Vay LL, Nghia TT and Walton M (2007). Comparative performance of hatchery-reared and wild Scylla paramamosain (Estampador, 1949) in pond culture. Aquac. Res. 38: 1593-1599.

Wang C (2009). Quantitative genetic estimates of growth-related traits in the common carp (Cyprinus carpio L) A review. Front. Biol. China 4: 298-304.

Wang Y, Chen Y, Han K, Zou Z, et al. (2012). A vasa gene from green mud crab Scylla paramamosain and its expression during gonadal development and gametogenesis. Mol. Biol. Rep. 39: 4327-4335.

Xu XJ, Wang GZ, Wang KJ and Li SJ (2009). Isolation and characterization of ten new polymorphic microsatellite loci in the mud crab, Scylla paramamosain. Conserv. Genet. 10: 1877-1878.

You W, Ke C, Luo X and Wang D (2010). Genetic correlations to morphological traits of small abalone Haliotis diversicolor. J. Shellfish Res. 29: 683-686.

Zeng C (2007). Induced out-of-season spawning of the mud crab, Scylla paramamosain (Estampador) and effects of temperature on embryo development. Aquac. Res. 38: 1478-1485. 